\title{
KARAKTER RELIGIUS PEMBELAJARAN IPA
}

\section{Susilawati}

Fakultas Tarbiyah dan Keguruan UIN Sultan Syarif Kasim Riau

Jl. H.R. Soebrantas No. 155 KM 18 Simpang Baru Panam, Pekanbaru 28293

E-mail: pku_susie@yahoo.com

\begin{abstract}
ABSTRAK
Pendidikan karakter yang merupakan salah satu prioritas pengembangan nasional 2010, selaras dengan tujuan pendidikan nasional. Pendidikan karakter yang diharapkan bukanlah subjek yang berdiri sendiri, atau nilai yang diajarkan, namun lebih merupakan upaya penanaman nilai-nilai melalui mata pelajaran secara terintegrasi. Belajar sain di tingkat sekolah dasar secara spesifik bertujuan untuk mengembangkan pengetahuan, sikap dan keterampilan dengan tujuan utamanya mengembangkan berfikir kreatif dan berfikir kritis. Nilai-nilai dapat ditanamkan melalui proses pembiasaan mata pelajaran sain yang mengadopsi nilai-nilai agama, kejujuran, toleransi, disiplin, bekerja keras, kreatif, mandiri, demokratis, keingintahuan, nasionalisme, patriotisme, keunggulan, persahabatan/komunikatif, cinta damai, gemar membaca, peduli lingkungan, peduli masyarakat, dan tanggung jawab. Aspek-aspek yang harus diperhitungkan dalam integrasi ini adalah mengaitkan nilai-nilai ini secara eksplisit dalam perencanaan, implementasi, penilaian proses belajar dengan karakter mata pelajaran.
\end{abstract}

Kata Kunci: Integrasi, Pendidikan karakter, IPA, Madrasah Ibtidaiyah

\section{ABSTRACT}

Character education as one of the national development priorities in 2010 must be coherent are in line with the national education goals. Expected character education is not a subject that stands alone or is a value that is tanght, but rather the effort to plant one of these values through the integration of subjects. Learning science in elementary school specifically aims to develop knowledge, attitudes and skills with the main objective to develop creativity and critical thinking. Values that can be implanted through a process of habituation in science subjects in primary schools are religious, honest, tolerance, discipline, hard work, creative, independent, democratic, curiosity, the spirit of nationalism, patriotism, recognize excellence, friendship/communicative, love peace, love reading, environmental care, social care, and responsibility. Aspects must be considered in the integration is to link these values explicitly in planning, implementing and assessing learning lessons tailored to the characteristics of the subjects.

Keywords: Integration, Character education, IP A, Madrasah Ibtidaiyah 


\section{PENDAHULUAN}

Dalam Instruksi Presiden No. 1 Tahun 2010 tentang Percepatan Pelaksanaan Prioritas Pembangunan Nasional Tahun 2010, salah satu bidang yang menjadi skala prioritas pembangunan nasional adalah pendidikan yang lebih menekankan pada pembelajaran aktif yang berdasarkan nilai-nilai budaya bangsa untuk membentuk daya saing dan karakter bangsa. Hal ini sejalan dengan Undang-Undang No. 20 Tahun 2003 tentang Sistem Pendidikan Nasional Pasal 3 , yang menyatakan bahwa pendidikan nasional berfungsi mengembangkan kemampuan dan membentuk watak serta peradaban bangsa yang bermartabat dalam rangka mencerdaskan kehidupan bangsa, bertujuan untuk mengembangkan potensi peserta didik agar menjadi manusia yang beriman dan bertakwa kepada Tuhan Yang Maha Esa, berakhlak mulia, sehat, berilmu, cakap, kreatif, mandiri, dan menjadi warga negara yang demokratis serta bertanggung jawab.

Berdasarkkan Inpres dan UU di atas, dapat diketahui bahwa terdapat penekanan akan pentingnya pendidikan karakter. Pendidikan karakter menjadi isu utama pendidikan dan menjadi bagian dari proses pembentukan akhlak anak bangsa. Hal ini disebabkan banyaknya kasus-kasus aktual dalam dunia pendidikan yang menuntut penyelesaiannya sesegera mungkin, antara lain, masih banyak ditemukan siswa yang menyontek ketika sedang ujian, bersikap malas, tawuran antar sesama siswa, melakukan pergaulan bebas, terlibat narkoba, dan aksi geng motor. Pada saat yang bersamaan, ditemukan pula guru/pendidik yang melakukan kecurangan-kecurangan dalam sertifikasi dan dalam Ujian Nasional (UN).

Pembentukan karakter individu dapat dilakukan dengan cara pembiasaan yang mulai ditanamkan sejak usia dini di lingkungan informal (keluarga). Ternyata lingkungan keluarga belum memberikan kontribusi berarti dalam mendukung pencapaian kompetensi dan pembentukan karakter peserta didik. Kesibukan dan aktivitas kerja orang tua yang relatif tinggi, kurangnya pemahaman orang tua dalam mendidik anak di lingkungan keluarga, pengaruh pergaulan di lingkungan sekitar, ditambah dengan pengaruh media elektronik ditengarai bisa berpengaruh negatif terhadap perkembangan dan pencapaian hasil belajar peserta didik. Salah satu alternatif untuk mengatasi permasalahan tersebut adalah melalui pendidikan karakter terpadu, yaitu memadukan dan mengoptimalkan kegiatan pendidikan informal lingkungan keluarga dengan pendidikan formal di sekolah. Dalam hal ini, waktu belajar peserta didik di sekolah perlu dioptimalkan agar peningkatan mutu hasil belajar dapat dicapai, terutama dalam pembentukan karakter peserta didik, khususnya pada jenjang Madrasah Ibtidaiyah.

Sebagaimana terdapat dalam UU No. 20 Tahun 2003 tentang Sistem Pendidikan Nasional, pendidikan karakter tercermin dalam setiap satuan pendidikan dan diharapkan implementasinya tidak hanya dijadikan kurikulum baku, melainkan dibiasakan melalui proses pembelajaran. Karena pengembangan 
karakter merupakan proses yang panjang, terus menerus, dan berkesinambungan, bahkan dikatakan proses yang tidak akan pernah berhenti dan berakhir, maka pendidikan karakter menghendaki adanya pengintegrasian dengan setiap mata pelajaran dalam proses pembelajaran. Materi pembelajaran yang berkaitan dengan norma atau nilai-nilai pada setiap mata pelajaran perlu dikembangkan, dieksplisitkan, dikaitkan dengan konteks kehidupan sehari-hari. Dengan demikian, pembelajaran nilai-nilai karakter tidak hanya pada tataran kognitif, tetapi menyentuh pada internalisasi, dan pengamalan nyata dalam kehidupan peserta didik sehari-hari di masyarakat.

Salah satu mata pelajaran yang terdapat di Madrasah Ibtidaiyah adalah Mata Pelajaran Ilmu Pengetahuan Alam (IPA). Menurut kurikulum IPA di Madrasah Ibtidaiyah, IPA merupakan cara mencari tahu tentang alam sekitar secara sistematis untuk mengusai pengetahuan, fakta-fakta, konsep-konsep, prinsip-prinsip, proses penemuan, dan memiliki sikap ilmiah. Pendidikan IPA bermanfaat bagi siswa untuk mempelajari diri sendiri dan alam sekitar. Pendidikan IPA menekankan pada pemberian pengalaman langsung dan kegiatan praktis untuk mengembangkan kompetensi agar siswa memahami alam sekitar secara ilmiah. Pendidikan IPA diarahkan untuk mencari tahu dan berbuat sehingga dapat membantu siswa untuk memperoleh pemahaman yang lebih mendalam tentang alam sekitar.

Berdasarkan deskripsi di atas, terdapat hal pentig untuk dikaji lebih serius tentang pengembangan pendidikan karakter melalui integrasi mata pelajaran IPA di Madrasah Ibtidaiyah. Nilai-nilai mata pelajaran IPA di atas dapat ditanamkan kepada siswa Madrasah Ibtidaiyah melalui teknik pembiasaan.

\section{PEMBAHASAN}

\section{Pendidikan Karakter}

Kata karakter berasal dari kata Yunani, charasein, yang berarti mengukir sehingga terbentuk sebuah pola. Dalam bahasa Arab, karakter sepadan dengan konsep akhlak (khuluk), yaitu tabiat atau kebiasaan melakukan hal yang baik. Dengan demikian, karakter adalah watak, tabiat, akhlak, atau kepribadian seseorang yang terbentuk dari hasil internalisasi berbagai kebajikan (virtues) yang diyakini dan digunakan sebagai landasan cara pandang, berpikir, bersikap, dan bertindak. Kebajikan terdiri atas sejumlah nilai, moral, dan norma, seperti jujur, berani bertindak, dapat dipercaya, dan hormat kepada orang lain.

Menurut Sudrajat (2010), karakter merupakan nilai-nilai perilaku manusia yang berhubungan dengan Tuhan Yang Maha Esa, diri sendiri, sesama manusia, lingkungan dan kebangsaan yang terwujud dalam pikiran, sikap, perasaan, perkataan, dan perbuatan, berdasarkan norma-norma agama, hukum, tata krama, budaya dan adat istiadat.

Pendidikan merupakan upaya terencana dalam mengembangkan potensi peserta didik, sehingga mereka memiliki sistem berpikir, nilai, moral, dan keyakinan yang diwariskan serta dikembangkan ke arah yang sesuai untuk 
kehidupan masa kini dan masa mendatang. Berarti, pendidikan karakter adalah suatu sistem penanaman nilai-nilai karakter kepada warga sekolah yang meliputi komponen pengetahuan, kesadaran atau kemauan, dan tindakan sendiri, sesama, lingkungan, maupun kebangsaan sehingga menjadi manusia paripurna kamil. Menurut Megawangi (2009) mengutip pernyataan Ibnu Jazzar Al-Qairawani, pendidikan karakter diperlukan dalam rangka memberikan pengetahuan "akan mana yang baik dan mana yang buruk", serta membantu sifat-sifat baik agar mengakar di dalam diri anak sehingga membuatnya menjadi seorang yang berkarakter (insan kamil). Artinya, pendidikan karakter pun merupakan usaha untuk mencegah tumbuhnya sifat-sifat buruk yang dapat menutupi fitrah manusia, serta melatih anak untuk terus-menerus melakukan perbuatan baik agar mengakar kuat dalam dirinya sehingga tercermin dalam perilakunya tindakantindakan kebajikan.

Karakter yang ada pada diri individu tidak secara otomatis diperoleh sejak individu tersebut dilahirkan, melainkan melalui proses yang panjang yang salah satunya dapat ditempuh melalui proses pendidikan. Berdasarkan pendapat pakar pendidikan, terbentuknya karakter pada individu dipengaruhi oleh dua faktor yaitu nature (faktor alami atau fitrah) dan nurture (sosialisasi dan pendidikan). Pada hakikatnya, fitrah manusia menurut perspektif agama adalah cenderung kepada kebaikan namun masih mengakui adanya pengaruh lingkungan yang dapat mengganggunya proses tumbuhnya fitrah. Sebagaimana firman Allah dalam hadis Qudsi: sesunggubnya Aku telah menciptakan hamba-hamba-Ku dalam keadaan luru, suci, dan bersih. Kemuadian datanglah setan-setan yang menggelincirkan mereka dan menyesatkannya ari kebenaran agama mereka. Dan setan-setan pun telah mengharamkan sesuatu bagi mereka apa-apa yang telah Aku balalkan.

Munir (2010) menggunakan istilah gen dalam faktor yang mempengaruhi terbentuknya karakter individu yang dibawa sejak lahir. Munir menyatakan bahwa gen merupakan salah satu faktor penentu dalam pembentukan karakter individu dan menanamkan kebiasaan yang dilakukan berulang-ulang. Pembentukan karakter didahului oleh kesadaran dan pemahaman akan karakter itu sendiri. Oleh sebab itu, gen merupakan faktor penentu pertama yang melekat pada diri individu. Ketika tidak ada proses berikutnya (pendidikan) yang berpengaruh secara kuat dalam, sosialisasi atau beradaptasi dengan lingkungan, boleh jadi, faktor genetis ini yang akan menjadi karakter individu.

\section{Hakikat IPA}

Dari sudut bahasa, IPA atau science berasal dari bahasa latin, yaitu dari kata scientia artinya pengetahuan. Secara harfiah science dapat disebut sebagai ilmu tentang alam dan peristiwa-peristiwa yang terjadi di alam (Iskandar, 1996). Secara etimologis yaitu berasal dari bahasa Jerman yang merujuk pada kata Wissenschaft. Science dalam arti ini memiliki pengertian sebagai pengetahuan yang tersusun dan terorganisasikan secara sistematis (Nugraha, 2008). 
Menurut Benjamin (dalam Liem, 2007), seorang filosof IPA mendefinisikan IPA sebagai "suatu cara penyelidikan yang mencoba sampai ke informasi mengenai dunia (alam semesta) dengan menggunakan metode pengamatan dan metode hipotesis-hipotesis yang telah teruji yang didasarkan pada pengamatan". Carin (1997) mendefinisikan IPA sebagai pengetahuan yang tersusun secara sistematik, berlaku umum, berupa kumpulan data hasil observasi dan eksperimen, yang digunakan secara terbatas pada gejala-gejala alam. Perkembangan IPA ditunjukkan tidak hanya oleh kumpulan fakta saja, tetapi juga oleh timbulnya metode ilmiah dan sikap ilmiah. Jadi, pada dasarnya IPA dapat dipandang sebagai produk dan proses. Sund (1973) menyatakan, science is both a body knowledge and a process. Pernyataan tersebut mengandung arti bahwa IPA mempunyai dua dimensi, yaitu IPA sebagai produk dan IPA sebagai proses.

Sebagai produk, IPA merupakan ilmu pengetahuan yang terstruktur yang diperoleh melalui proses aktif, dinamis, eksploratif berdasarkan asas penalaran induktif. IPA sebagai pengetahuan, khususnya tentang fakta atau prinsip yang diperoleh melalui kajian sistematik, merupakan cabang khusus pengetahuan yang berkaitan dengan fakta-fakta atau kebenaran yang diatur secara sistematik. IPA sebagai proses di dalamnya mengandung sikap ilmiah (scientific attitude) yang merupakan faktor sentral dalam menyokong perkembangan ilmu.

Berdasarkan pengertian di atas, dapat dipahami bahwa IPA dapat dipandang sebagai suatu kesatuan dari proses, sikap dan hasil. Abruscato (1982) menegaskan bahwa IPA pada dasarnya berisi sikap disamping produk dan proses.

Agar lebih jelas, gambaran tentang batasan IPA sebagai produk, proses, dan terutama sikap dapat dijelaskan sebagai berikut:

1. IPA sebagai Produk

IPA sebagai produk ilmiah dapat berupa pengetahuan IPA yang dapat ditemukan di dalam buku-buku ajar, majalah-majalah ilmiah, buku-buku teks, artikel ilmiah yang terbit pada jurnal, serta pernyataan-pernyataan para ahli IPA. Sulistyorini (2007) menyatakan, IPA sebagai poduk merupakan akumulasi hasil upaya para perintis IPA terdahulu yang umumnya terarah, tersusun secara lengkap dan sistematis dalam bentuk buku teks. Pengetahuan IPA dibangun melalui penalaran inferensi yang berdasarkan data yang tersedia. Kebenarannya diuji lewat pengamatan nyata.

Produk IPA itu dapat dibagi menjadi: fakta, konsep, lambang, konsepsi/penjelasan, dan teori. Carin (1997) menyebutkan bentuk IPA sebagai suatu produk terdiri atas berbagai fakta, konsep, prinsip, hukum dan teori. Menurut Iskandar (1996) IPA sebagai produk merupakan kumpulan hasil kegiatan empirik dan kegiatan analitik yang dilakukan oleh para ilmuwan selama berabad-abad.

Ketika para ilmuwan mengamati suatu fenomena alam, mereka memperoleh sejumlah fakta dan informasi tentang hal-hal yang terkait dengan 
fenomena tersebut. Mereka selanjutnya membangun konsep-konsep IPA berupa sebuah kata atau gabungan dua kata atau lebih. Untuk mempermudah komunikasi di antara mereka sendiri dan dengan masyarakat umum, para pakar menyusun banyak lambang/simbol. Penjelasan para ahli tentang suatu fenomena disajikan dalam bentuk deskripsi yang dinyatakan dengan konsep-konsep IPA yang disusun saat itu atau konsep-konsep yang telah ada sebelumnya dan dengan hubungan antar konsep yang terjadi. Definisi merupakan salah satu bentuk deskripsi formal dari suatu konsep. Hubungan antar konsep disajikan dalam bentuk teori, hukum, dan rumus IPA. Berdasarkan konsep-konsep IPA ini dibangunlah teori. Ada banyak pengertian tentang teori. Teori sering dipadankan dengan terkaan, opini, atau spekulasi. Dalam IPA, teori merupakan deskripsi matematis, penjelasan logis, hipotesis yang telah diverifikasi, atau suatu model interaksi dalam suatu fenomena alam yang telah dibuktikan kebenarannya (Sutrisno, et, al., 2007).

Mata pelajaran IPA berisi sejumlah fakta, konsep, prinsip, hukum, teori yang merupakan hasil (produk) penemuan para ilmuwan sebelumnya dan mengalami perkembangan yang sangat pesat. Pesatnya perkembangan ilmu pengetahuan, membuat para ilmuwan senantiasa terus berpikir, meneliti dan menghasilkan temuan-temuan baru. Produk ilmu yang mereka hasilkan juga selalu bertambah dari waktu ke waktu. Oleh karena itu, perlu kejelian guru untuk memilih dan memilah ilmu mana yang harus dikuasai siswa. Dalam hal ini, menurut Firman dan Widodo (2007) seorang guru selain mempelajari ilmu sebagai produk maka perlu mempelajari bagaimana cara mencari dan mengembangkan ilmu. Siswa harus dibekali bagaimana cara mencari, memilah, dan menemukan cara untuk mempelajari ilmu.

2. IPA sebagai Proses

IPA sebagai suatu proses adalah serangkaian metode untuk memperoleh atau mendapatkan IPA (Nugraha, 2008; Sulistyorini, 2007). IPA dipandang sebagai suatu disiplin ilmu yang ketat, objektif dan bebas nilai. IPA menuntut proses yang dinamis dalam berfikir, mengamati, bereksperimen, menemukan maupun merumuskan berbagai konsep dan teori. IPA sebagai proses merujuk pada suatu aktivitas yang dilakukan para ilmuwan. Setiap aktivitas ilmiah mempunyai ciri rasional, kognitif dan bertujuan. Rangkaian proses yang dilakukan dalam kegiatan IPA disebut metode ilmiah. Jadi, IPA sebagai proses berisi metode ilmiah (Nugraha, 2008). Metode ilmiah merupakan ekspresi dari proses mental, yaitu cara berpikir logis dan sistematik.

Bagi siswa Madrasah Ibtidaiyah (MI), metode ilmiah dikembangkan secara bertahap dan berkesinambungan, dengan harapan akan terbentuk paduan yang lebih utuh sehingga siswa MI dapat melakukan penelitian sederhana. Tahapan pengembangannyapun disesuaikan dengan langkah-langkah proses penelitian, yakni meliputi: observasi, klasifikasi, interpretasi, prediksi, hipotesis, mengendalikan variabel, merencanakan dan melaksanakan penelitian, inferensi, 
aplikasi dan komunikasi (Sulistyorini, 2007; Iskandar, 1996). Dengan melatih berpikir ilmiah ini, siswa menjadi terampil berpikir proses, mengikuti rangkaian langkah-langkah metode ilmiah atau langkah-langkah logis lainnya. Langkahlangkah ini merupakan dasar pendekatan keterampilan proses.

Agar siswa MI kelak dapat mengembangkan ilmu seperti halnya para ilmuwan, maka mereka harus menguasai (bukan sekedar mengetahui) kemampuan dasar bekerja ilmiah. Kemampuan dasar bekerja ilmiah yang harus dikuasai siswa MI (Firman dan Widodo , 2007) adalah:

a. Mengamati

Mengamati merupakan usaha untuk mendapatkan gambaran tentang suatu benda atau suatu fenomena. Tanpa adanya kemampuan mengamati tidak akan mendapatkan gambaran yang baik sehingga tidak akan dapat mengembangkan ilmu. Mengamati bukan hanya sekedar melihat. Mengamati merupakan proses pendeskripsian dengan menggunakan alat indera yang dimiliki. Prinsipnya, semakin banyak alat indera yang terlibat dalam proses pengamatan, hasil pengamatan akan semakin baik sebab gambaran yang diperoleh juga semakin lengkap. Dalam pengamatan seringkali diperlukan alat bantu. Berarti, kemampuan menggunakan alat juga sangat penting. Agar siswa MI terampil dengan menggunakan alat bantu, sebaiknya sejak dini mereka telah dilatih menggunakan beberapa alat yang banyak digunakan dalam IPA.

b. Menafsirkan

Menafsirkan mencakup keterampilan untuk menghubungkan hal yang satu dengan hal lainnya. Keterampilan menafsirkan membantu dalam menemukan persamaan, perbedaan, pola, dan keteraturan.

c. Membuat hipotesis

Keterampilan berhipotesis mencakup keterampilan menemukan hubungan antara dua atau lebih variabel, atau mengajukan perkiraan penyebab terjadinya sesuatu hal. Dengan hipotesis diungkapkan cara melakukan pemecahan masalah, karena dalam rumusan hipotesis biasanya terkandung cara untuk mengujinya.

d. Merencanakan percobaan

Hipotesis yang telah dirumuskan harus diuji kebenarannya melalui pengamatan dan percobaan. Keterampilan merencanakan percobaan merupakan keterampilan yang kompleks dan berkaitan erat dengan keterampilan proses lainnya. Keterampilan ini mendorong kemandirian siswa dalam melakukan penelitian dan praktikum.

e. Mengomunikasikan

Keterampilan berkomunikasi mencakup keterampilan menyampaikan dan menerima informasi. Keteramapilan berkomunikasi mencakup kemampuan menggunakan bermacam bentuk komunikasi baik lisan maupun tulisan. Dalam komunikasi ilmiah sering dituntut kemampuan untuk menyajikan dan membaca informasi secara mudah dan akurat, seperti pemilahan bentuk 
penyajian yang tepat dan menjelaskan hasil percobaan serta menyampikan laporan secara sistematis dan jelas.

Berdasarkan uraian di atas, fokus utama IPA sebagai proses adalah kemampuan berupaya memecahkan masalah yang tertentu. Berarti, para siswa MI didorong untuk menguasai dan menggunakan sejumlah keterampilan dan keahlian seperti para ilmuwan dalam memecahkan masalah ilmiah. Berbagai keahlian dan keterampilan ini sangat bernilai bagi siswa MI baik untuk memahami pelajaran IPA maupun ketika digunakan di luar konteks pelajaran (Sumintono, 2008).

3. IPA sebagai Sikap

Dalam memecahkan suatu masalah seorang ilmuwan sering berusaha mengambil sikap tertentu sehingga memungkinkan mencapai hasil yang diharapkan. Sikap itu dikenal dengan sebutan sikap ilmiah. Sikap ilmiah merupakan berbagai keyakinan, opini dan nilai-nilai yang harus dipertahankan oleh seorang ilmuwan, khususnya ketika mencari atau mengembangkan pengetahuan baru. Mengacu pada pendapat Harlen (1992), setidaknya ada sembilan aspek sikap ilmiah yang dapat diajarkan kepada siswa MI, yaitu: (1) sikap ingin tahu, (2) sikap ingin mendapatkan sesuatu yang baru, (3) sikap kerja sama, (4) sikap tidak putus asa, (5) sikap tidak berprasangka, (6) sikap mawas diri, (7) sikap bertanggung jawab, (8) sikap berpikir bebas, dan (9) sikap kedisiplinan diri.

Menurut Harlen (1992) untuk menumbuhkembangkan sikap ilmiah siswa ada tiga peran utama guru, yakni: memperlihatkan contoh, memberikan penguatan dengan pujian dan persetujuan, dan memberikan kesempatan untuk mengembangkan sikap. Selagi siswa menunjukkan keinginan untuk berbuat, harus diberikan kesempatan untuk beraktivitas. Memberikan objek baru adalah memberikan kesempatan pada siswa untuk mengembangkan sikap ingin tahu. Mendiskusikan hasil eksperimen memberikan kesempatan pada siswa untuk berpikir kritis. Salah satu cara untuk mengembangkan sikap ilmiah adalah dengan memperlakukan siswa seperti ilmuwan muda sewaktu anak mengikuti kegiatan pembelajaran IPA.

Berdasarkan tiga hakikat IPA di atas, dapat diketahui batasan bidang kajian IPA. Menurut Poedjiadi (1987), batasan IPA adalah sekelompok pengetahuan tentang obyek dan fenomena alam, yang diperoleh dari hasil pemikiran dan penelitian para ilmuwan, yang dilakukan dengan keterampilan bereksperimen, serta dengan menggunakan metode ilmiah. Objek dan fenomena alam tersebut berada dalam keteraturan dan mengikuti hukum-hukum alam, serta melibatkan konsep-konsep yang saling berhubungan. Hasil atau kesimpulan yang diperoleh dari penelitian bersifat sementara. IPA dibagi ke dalam disiplin-disiplin tertentu seperti fisika, kimia dan biologi. Pembagian terjadi karena keterbatasan kemampuan seseorang untuk mempelajari dari segala aspek tentang fenomena alam secara mendalam. Suyudi (2003) menambahkan bahwa ada keterbatasan 
dalam IPA, yaitu: (1) IPA tidak menjangkau ketika ditujukan untuk menguji kebenaran adanya Tuhan, (2) IPA tidak menjangkau secara sempurna tentang objek pengamatannya, dan (3) IPA tidak menjangkau masalah etika dan estetika.

\section{Pembelajaran IPA}

Menurut Pusat Kurikulum (2007), pembelajaran IPA di Madrasah Ibtidaiyah hendaknya memperhatkan: (1) perencanaan pembelajaran diarahkan pada pembelajaran berbasis penyelidikan ilmiah, (2) pembelajaran berpusat kepada siswa, guru bertindak sebagai pembimbing dan fasilitator, (3) pengembangan lingkungan belajar sebagai sumber belajar kontekstual, (4) pembelajaran IPA menciptakan komunitas pebelajar IPA, (5) pembelajaran IPA menggunakan berbagai pendekatan, seperti Contextual Teaching Learning (CTL) dan pendekatan keterampilan proses, untuk mengembangkan kemampuan observasi, merencanakan penyelidikan, menasirkan data, dan informasi (narasi, gambar, bagan, tabel) serta menarik kesimpulan, (6) IPA diajarkan sesuai dengan hakikat IPA, yaitu produk, proses dan sikap, (7) kerja ilmiah mulai diajarkan kepada siswa kelas empat dan terus berkelanjutan sampai kelas 12 untuk menumbuhkan pengertian dan kemampuan yang berhubungan dengan pemersatu konsep dan proses melalui pengalaman belajar, dan (8) pembelajaran IPA menekankan pada pembelajaran inkuiri, kontekstual dan pemecahan masalah.

Berdasarkan Sutrisno dan Kartono (2007), dapat ditambahkan bahwa prinsip-prinsip pembelajaran IPA di MI hendaknya memperhatikan hal-hal sebagai berikut: (1) memiliki pemahaman tentang dunia sekitar dimulai melalui pengalaman baik secara inderawi maupun non inderawi, (2) pengetahuan yang diperoleh tidak pernah terlihat secara langsung sehingga perlu diungkap selama proses pembelajaran, (3) pengetahuan dan pengalaman siswa pada umumnya kurang konsisten dengan pengetahuan para ilmuwan dan pengetahuan yang dimiliki oleh guru, (4) dalam setiap pengetahuan mengandung fakta, data, konsep, lambang, dan relasi dengan konsep yang lain, dan (5) IPA terdiri atas produk, proses, dan sikap.

Dalam pembelajaran IPA perlu lebih menekankan proses berpikir dan aktivitas-aktivitas saintis, dengan metode pembelajaran yang mengarah untuk menggali proses berpikir dalam IPA. Pembelajaran IPA dilakukan seperti bagaimana IPA itu ditemukan, pembelajaran IPA dilaksanakan melalui sebuah proses yang berbasis pada penyelidikan ilmiah. Menurut Rustaman (1996) pembelajaran IPA yang hanya menekankan pada salah satu aspek hakikat IPA (produk atau proses) tidak diharapkan. Bagaimanapun juga, saat ini, metodologi pembelajaran IPA hampir semuanya menekankan pada pengembangan keterampilan proses, tidak lagi ditujukan pada pemahaman konsep saja. Dahar (1990) menambahkan, apabila hanya mengajarkan IPA sebagai produk yakni berupa fakta-fakta, konsep-konsep, prinsip-prinsip dan teori-teori, kepada siswa 
tanpa mengetahui IPA sebagai proses berarti bukan mengajarkan IPA, karena antara produk IPA dan proses IPA tidak dapat dipisahkan.

Menurut Abruscato (1982) pembelajaran IPA secara spesifik bertujuan untuk mengembangkan pengetahuan, sikap dan keterampilan; dengan tujuan utama untuk mengembangkan kreativitas dan berpikir kritis. Trihastuti dan Yoko (2008) menjelaskan bahwa pembelajaran IPA pada prinsipnya mengembangkan tiga ranah kompetensi, yaitu ranah kognitif, ranah afektif, dan ranah psikomotor. Ranah kognitif berupa konsep, prinsip, hukum dan teori. Ranah afektif berupa sikap keteguhan hati, keingintahuan, dan ketekunan dalam menyingkapi rahasia alam. Ranah psikomotor merupakan proses ilmiah, baik fisik maupun mental, dalam mencermati fenomena alam.

Tiga ranah di atas menggiring ke arah pengertian hakikat IPA yang meliputi apa yang dikaji, bagaimana cara memperoleh, dan sikap serta nilai-nilai apa yang terbentuk. Ketiga komponen penting dalam hakikat IPA adalah sebagai berikut: (1) IPA merupakan kumpulan pengetahuan ilmiah yang disusun secara logis dan sistematis, hal ini yang menunjukkan IPA sebagai produk; (2) IPA diperoleh melalui proses ilmiah. Proses ilmiah berupa langkah-langkah ilmiah yang berdasarkan pada metode ilmiah. Proses ilmiah dapat berupa fisik dan mental dalam mencermati fenomena alam, termasuk juga penerapannya; dan (3) IPA dapat mengembangkan sikap dan nilai-nilai. Dalam pembelajaran IPA diharapkan tumbuh kembang sikap keteguhan hati, keingintahuan, dan ketekunan dalam menyingkap rahasia alam dan sikap ilmiah lainnya.

Tiga ranah kompetensi yang terkandung pada pelajaran IPA ini sangat erat dengan hakikat IPA yaitu IPA sebagai pengetahuan, IPA sebagai proses dan IPA sebagai nilai-nilai serta sikap ilmiah. Penilaian tentang kemajuan belajar siswa dilakukan dengan cara penilaian kelas, yaitu dilakukan selama proses pembelajaran secara terintegrasi atau tidak dipisahkan dari kegiatan pembelajaran dalam arti kemajuan belajar dinilai dari proses dan pada akhir periode.

Pembelajaran IPA di sekolah hendaknya tidak diarahkan semata-mata menyiapkan anak didik untuk melanjutkan ke jenjang pendidikan yang lebih tinggi, namun yang lebih penting adalah menyiapkan anak didik untuk (1) mampu memecahkan masalah yang dihadapi dalam kehidupan sehari-hari dengan menggunakan konsep-konsep IPA yang telah mereka pelajari, (2) mampu mengambil keputusan yang tepat dengan menggunakan konsep-konsep ilmiah, dan (3) mempunyai sikap ilmiah dalam memecahkan masalah yang dihadapi sehingga memungkinkan mereka untuk berpikir dan bertindak secara ilmiah (Ndraka dalam Trihastuti dan Yoko, 2008). Gagasan belajar IPA yang tidak sekedar belajar sederetan fakta IPA sudah lama dicanangkan dan secara ekplisit dikenalkan sejak Kurikulum 1975. Gagasan ini berimplikasi pada strategi pembelajaran IPA, yang mulai bergeser dari praktik pembelajaran yang berorientasi telling science ke orientasi doing science. Menurut Beyer (dalam Rustaman, 2007); untuk mengembalikan pembelajaran IPA, pada hakikatnya metode inkuiri merupakan strategi sentral dalam pembelajaran IPA. Melalui 
inkuiri, dimungkinkan pembelajaran yang melibatkan proses, produk atau pengetahuan (content, knowledge) dengan konteks dan nilai (context, values, affective).

\section{"Karakter" dalam Pembelajaran IPA di Madrasah Ibtidaiyah}

Pendidikan merupakan mekanisme institusional yang akan mengakselerasi pembinaan karakter bangsa dan juga berfungsi sebagai arena mencapai tiga hal yang mendasar dalam pembinaan karakter bangsa yaitu reaktivasi karakter luhur bangsa, membangun karakter inovatif serta kompetitif dan menginternalisasikan dalam segenap sendi-sendi kehidupan bangsa dan program pemerintah yang merupakan suatu concerted efforts dari seluruh masyarakat dan pemerintah (Rajasa dalam Muslich: 2011). Pencapaian tersebut menghendaki suatu proses yang berkelanjutan, salah satunya melalui terobosan kurikulum pada mata pelajaran.

Pengembangan pendidikan karakter di Madrasah Ibtidaiyah tidak hanya pada mata pelajaran Agama atau pendidikan kewarganegaraan saja namun dapat diintegrasikan pada semua mata pelajaran yang terdapat pada kurikulum Madrasah Ibtidaiyah. Salah satu mata pelajaran yang terdapat pada kurikulum Madrasah Ibtidaiyah adalah IPA. IPA merupakan salah satu mata pelajaran yang ada dalam kurikulum Madrasah Ibtidaiyah, yang menekankan pada penanaman nilai, karena IPA merupakan cara mencari tahu tentang alam sekitar secara sistematis untuk mengusai pengetahuan, fakta-fakta, konsep-konsep, prinsipprinsip, proses penemuan, dan memiliki sikap ilmiah.

Pembelajaran IPA di Madrasah Ibtidaiyah secara spesifik bertujuan untuk mengembangkan pengetahuan, sikap dan keterampilan; dengan tujuan utama untuk mengembangkan kreativitas dan berpikir kritis. Nilai-nilai yang dapat ditanamkan melalui proses pembiasaan pada mata pelajaran IPA di Madrasah Ibtidaiyah adalah religius, jujur, toleransi, disiplin, kerja keras, kreatif, mandiri, demokratis, rasa ingin tahu, semangat kebangsaan, cinta tanah air, menghargai prestasi, bersahabat/komunikatif, cinta damai, gemar membaca, peduli lingkungan, peduli sosial, dan tanggung jawab.

Pengintegrasian pendidikan karakter pada mata pelajaran dengan memperhatkan materi pembelajaran yang berkaitan dengan norma atau nilai-nilai yang ada pada mata pelajaran perlu dikembangkan, dieksplisitkan, dikaitkan dengan konteks kehidupan sehari-hari. Pembelajaran nilai-nilai karakter tidak hanya pada tataran kognitif, tetapi menyentuh pada internalisasi, dan pengalaman nyata dalam kehidupan sehari-hari di masyarakat. Buchori (dalam Sudrajat, 2010) menyatakan bahwa pendidikan karakter seharusnya membawa peserta didik ke pengenalan secara kognitif, penghayatan nilai secara afektif, dan akhirnya ke pengalaman nilai secara nyata. Hal ini sejalan dengan konsep pembelajaran IPA di Madrasah Ibtidaiyah sebagaimana yang dituntut dalam kurikulum tingkat satuan pendidikan. Pembelajaran IPA menekankan pada pemberian pengalaman langsung dan kegiatan praktis untuk mengembangkan kompetensi agar siswa memahami alam sekitar secara ilmiah (BSNP, 2006). 
Aspek yang harus diperhatikan dalam pengintegrasian adalah mengaitkan nilai-nilai tersebut secara eksplisit dalam perencanaan pembelajaraan, pelaksanaan pembelajaran dan penilaian pembelajaran yang disesuaikan dengan karakteristik mata pelajaran. Megawangi (2009) menegaskan bahwa usaha pembentukkan karakter memerlukan pendekatan komprehensif yang dilakukan secara eksplisit, sistematis dan berkesinambungan.

Pengintegrasian pendidikan karakter dalam mata pelajaran IPA pun harus dieksplisitkan, sehingga guru IPA dapat melakukan hal-hal di bawah ini:

1) Melakukan analisis Standar Kompetensi dan Kompetensi Dasar serta pemataan materi pembelajaran.

2) Melakukan analisis tokoh di balik sebuah konsep IPA untuk menemukan nilai-nilai kehidupan apa yang diterapkannya sehingga menjadi orang sukses.

3) Memposisikan IPA sebagai mata pelajaran yang mengkaji, mempelajari, dan membuktikan kebesaran-kebesaran Allah SWT dan ketetapanketetapan-Nya untuk alam semesta.

4) Merumuskan indikator pencapaian SK dan KD dengan menyertakan kualitas-kualitas moral, bahkan spiritual. Sebagai contoh bisa diperhatikan rumusan berikut ini:

a) Siswa dapat menjelaskan konsep.............. dengan tepat dan percaya diri.

b) Siswa dapat menerapkan konsep...............secara mandiri dan jujur.

c) Siswa dapat menyebutkan aspek kebesaran Allah swt dalam konsep.

5) Mengembangkan proses pembelajaran aktif untuk internalisasi nilai.

Kemendiknas (2010), dalam pedoman sekolah pengembangan pendidikan budaya dan karakter bangsa, menyatakan bahwa pengembangan nilai-nilai pendidikan budaya dan karakter bangsa diintegrasikan dalam setiap pokok bahasan mata pelajaran. Nilai-nilai tersebut dicantumkan dalam silabus dan RPP. Pengembangan nilai-nilai itu dalam silabus ditempuh melalui cara-cara berikut ini:

1) Mengkaji Standar Komptensi (SK) dan Kompetensi Dasar (KD) pada Standar Isi (SI) untuk menentukan apakah nilai-nilai budaya dan karakter bangsa yang tercantum itu sudah tercakup di dalamnya;

2) Memperlihatkan keterkaitan antara SK dan $\mathrm{KD}$ dengan nilai dan indikator untuk menentukan nilai yang akan dikembangkan;

3) Mencantumkankan nilai-nilai budaya dan karakter bangsa ke dalam silabus;

4) Mencantumkan nilai-nilai yang sudah tertera dalam silabus ke dalam RPP; 
5) Mengembangkan proses pembelajaran peserta didik secara aktif yang memungkinkan peserta didik memiliki kesempatan melakukan internalisasi nilai dan menunjukkannya dalam perilaku yang sesuai; dan

6) Memberikan bantuan kepada peserta didik, baik yang mengalami kesulitan untuk menginternalisasi nilai maupun untuk menunjukkannya dalam perilaku.

Setiap kompetensi dasar memiliki kemampuan mengembangkan satu atau lebih nilai dan setiap nilai memiliki satu atau lebih indikator. Berikut ini disajikan peta yang menggambarkan keterkaitan antara SK dan KD dengan nilai dan indikator untuk nilai terkait.

Tabel 1. Keterkaitan antara SK dan KD dengan Nilai dan Indikator pada Mata Pelajaran IPA di Madrasah Ibtidaiyah

\begin{tabular}{|c|c|c|c|c|}
\hline \multirow{2}{*}{$\begin{array}{c}\text { Standar } \\
\text { Kompeten-si }\end{array}$} & \multirow{2}{*}{$\begin{array}{c}\text { Kompetensi } \\
\text { Dasar }\end{array}$} & \multirow{2}{*}{ Nilai } & \multicolumn{2}{|c|}{ Indikator Berdasarkan Jenjang Kelas } \\
\hline & & & \begin{tabular}{|c|}
$1-3$ \\
\end{tabular} & $4-6$ \\
\hline \multirow[t]{5}{*}{$\begin{array}{l}\text { mengenal } \\
\text { anggota tubuh }\end{array}$} & $\begin{array}{l}\text { mengenal bagian } \\
\text { tubuh dan } \\
\text { perawatannya }\end{array}$ & rasa ingin tahu & $\begin{array}{l}\text { menunjukkan pengamatan yang } \\
\text { serius terhadap anggota } \\
\text { tubuhnya }\end{array}$ & $\begin{array}{l}\text { mengajukan } \\
\text { pertanyaan yang } \\
\text { berkaitan dengan } \\
\text { fungsi anggota tubuh } \\
\text { dan perawatan nya } \\
\end{array}$ \\
\hline & & senang membaca & $\begin{array}{l}\text { mengemukakan dengan antusias } \\
\text { fungsi bagian-bagian tubuh } \\
\text { berdasarkan hasil bacaan }\end{array}$ & $\begin{array}{l}\text { mengemukakan } \\
\text { dengan antusias cara } \\
\text { merawat bagian-bagian } \\
\text { tubuh berdasarkan } \\
\text { hasil bacaan }\end{array}$ \\
\hline & & peduli sosial & $\begin{array}{l}\text { tidak mengolok-olok teman } \\
\text { yang memiliki keterbatasan fisik } \\
\text { (anggota tubuh) }\end{array}$ & $\begin{array}{l}\text { mau berkomunikasi } \\
\text { dengan teman yang } \\
\text { mengalami } \\
\text { keterbatasan fisik } \\
\text { (anggota tubuh) } \\
\end{array}$ \\
\hline & $\begin{array}{l}\text { mengidentifikasi } \\
\text { kebutuhan tubuh } \\
\text { agar tumbuh sehat } \\
\text { dan kuat (makanan, } \\
\text { air, pakaian, udara, } \\
\text { lingkungan sehat) }\end{array}$ & rasa ingin tahu & $\begin{array}{l}\text { menunjukkan antusiasme dalam } \\
\text { memperoleh informasi tentang } \\
\text { kebutuhan tubuh agar sehat dan } \\
\text { kuat }\end{array}$ & $\begin{array}{l}\text { menanyakan aspek lain } \\
\text { yang terkait dengan } \\
\text { kebutuhan tubuh agar } \\
\text { sehat dan kuat }\end{array}$ \\
\hline & & kerja keras & $\begin{array}{l}\text { menyimak penjelasan guru } \\
\text { dengan serius, mengajukan } \\
\text { pertanyaan dan pendapat } \\
\text { tentang kebutuhan tubuh agar } \\
\text { sehat dan kuat }\end{array}$ & $\begin{array}{l}\text { memilah } \\
\text { fakta/informasi yang } \\
\text { relevan dan tidak } \\
\text { relevan secara teliti } \\
\text { dalam mengidentifikasi } \\
\text { kebutuhan tubuh agar } \\
\text { sehat dan kuat } \\
\end{array}$ \\
\hline \multirow[t]{4}{*}{$\begin{array}{l}\text { mengenal } \\
\text { anggota tubuh }\end{array}$} & $\begin{array}{l}\text { membiasakan hidup } \\
\text { sehat }\end{array}$ & disiplin & $\begin{array}{l}\text { selalu mencuci tangan sebelum } \\
\text { dan sesudah makan }\end{array}$ & $\begin{array}{l}\text { membersihkan gigi } \\
\text { setelah makan }\end{array}$ \\
\hline & & $\begin{array}{l}\text { bersahabat/ } \\
\text { komunikatif }\end{array}$ & $\begin{array}{l}\text { membantu teman } \\
\text { membersihkan bagian tubuh } \\
\text { yang terkena kotoran }\end{array}$ & $\begin{array}{l}\text { membantu teman } \\
\text { membersihkan bagian } \\
\text { tubuh belakang yang } \\
\text { kotor }\end{array}$ \\
\hline & & peduli sosial & tidak meludah di tempat umum & $\begin{array}{l}\text { menutup mulut jika } \\
\text { batuk dan menutup } \\
\text { hidung jika bersin }\end{array}$ \\
\hline & & & buang air kecil/besar pada & membersihkan toilet \\
\hline
\end{tabular}




\begin{tabular}{|c|c|c|c|c|}
\hline \multirow{2}{*}{$\begin{array}{c}\text { Standar } \\
\text { Kompeten-si }\end{array}$} & \multirow{2}{*}{$\begin{array}{c}\text { Kompetensi } \\
\text { Dasar }\end{array}$} & \multirow{2}{*}{ Nilai } & \multicolumn{2}{|c|}{ Indikator Berdasarkan Jenjang Kelas } \\
\hline & & & $1-3$ & $4-6$ \\
\hline & & & tempatnya/ toilet & $\begin{array}{l}\text { atau tempat buang air } \\
\text { kecil/besar }\end{array}$ \\
\hline & & & $\begin{array}{l}\text { menutup mulut jika batuk dan } \\
\text { menutup hidung jika bersin }\end{array}$ & $\begin{array}{l}\text { menunjukkan upaya } \\
\text { aktif dalam bidang } \\
\text { kesehatan seperti } \\
\text { menjadi pengurus } \\
\text { UKS (Usaha } \\
\text { Kesehatan Sekolah) } \\
\text { atau menjadi donor } \\
\text { darah, dll. } \\
\end{array}$ \\
\hline \multirow{7}{*}{$\begin{array}{l}\text { mengenal cara } \\
\text { memelihara } \\
\text { lingkungan } \\
\text { agar tetap } \\
\text { sehat }\end{array}$} & $\begin{array}{l}\text { mengenal cara } \\
\text { menjaga lingkungan } \\
\text { agar tetap sehat }\end{array}$ & disiplin & $\begin{array}{l}\text { membuang sampah pada } \\
\text { tempatnya }\end{array}$ & $\begin{array}{l}\text { mengikuti jadwal piket } \\
\text { untuk memelihara } \\
\text { kebersihan ruangan } \\
\text { kelas }\end{array}$ \\
\hline & & senang membaca & $\begin{array}{l}\text { menjawab pertanyaan guru } \\
\text { dengan antusias tentang cara } \\
\text { menjaga lingkungan agar tetap } \\
\text { sehat berdasarkan hasil bacaan }\end{array}$ & $\begin{array}{l}\text { mengemukakan } \\
\text { pendapat dengan } \\
\text { antusias berdasarkan } \\
\text { hasil bacaan tentang } \\
\text { cara menjaga } \\
\text { lingkungan agar tetap } \\
\text { sehat }\end{array}$ \\
\hline & & ingin tahu & $\begin{array}{l}\text { menunjukkan antusiasme dalam } \\
\text { memperoleh informasi tentang } \\
\text { lingkungan sehat }\end{array}$ & $\begin{array}{l}\text { mengumpulkan } \\
\text { informasi dari guru } \\
\text { dan buku tentang } \\
\text { lingkungan sehat } \\
\end{array}$ \\
\hline & & & $\begin{array}{l}\text { menanyakan aspek lain yang } \\
\text { terkait dengan kebutuhan } \\
\text { lingkungan sehat }\end{array}$ & $\begin{array}{l}\text { mengumpul-kan } \\
\text { informasi dari berbagai } \\
\text { sumber (guru dan } \\
\text { buku) tentang } \\
\text { lingkungan sehat }\end{array}$ \\
\hline & $\begin{array}{l}\text { membedakan } \\
\text { lingkungan sehat } \\
\text { dengan lingkungan } \\
\text { tidak sehat }\end{array}$ & kerja keras & $\begin{array}{l}\text { menyimak penjelasan guru } \\
\text { dengan serius, mengajukan } \\
\text { pertanyaan tentang lingkungan } \\
\text { sehat dan tidak sehat }\end{array}$ & $\begin{array}{l}\text { memilah } \\
\text { fakta/informasi yang } \\
\text { relevan dan tidak } \\
\text { relevan secara teliti } \\
\text { dalam membedakan } \\
\text { lingkungan sehat dan } \\
\text { tidak sehat } \\
\end{array}$ \\
\hline & & peduli lingkungan & $\begin{array}{l}\text { bermain/duduk pada tempat } \\
\text { yang bersih di lingkungan } \\
\text { sekolah }\end{array}$ & $\begin{array}{l}\text { menunjukkan } \\
\text { kepedulian dalam } \\
\text { menjaga lingkungan } \\
\text { kelas agar tetap sehat } \\
\end{array}$ \\
\hline & & & $\begin{array}{l}\text { menunjukkan upaya menjaga } \\
\text { kebersihan bangku dan kursi } \\
\text { masing-masing }\end{array}$ & $\begin{array}{l}\text { menunjukkan } \\
\text { kepedulian dalam } \\
\text { menjaga lingkungan } \\
\text { sekolah agar tetap } \\
\text { sehat }\end{array}$ \\
\hline \multirow[t]{2}{*}{$\begin{array}{l}\text { mengenal cara } \\
\text { memelihara } \\
\text { lingkungan } \\
\text { agar tetap } \\
\text { sehat }\end{array}$} & $\begin{array}{l}\text { menceritakan } \\
\text { perlunya merawat } \\
\text { tanaman, hewan } \\
\text { peliharaan dan } \\
\text { lingkungan sekitar }\end{array}$ & senang membaca & $\begin{array}{l}\text { menceritakan dengan antusias } \\
\text { tentang perlunya merawat } \\
\text { tanaman, hewan dan lingkungan } \\
\text { berdasarkan hasil bacaan buku } \\
\text { paket }\end{array}$ & $\begin{array}{l}\text { menceritakan dengan } \\
\text { antusias tentang } \\
\text { perlunya merawat } \\
\text { tanaman, hewan dan } \\
\text { lingkungan } \\
\text { berdasarkan hasil } \\
\text { bacaan buku paket } \\
\text { dan buku } \\
\text { lainnya/buku } \\
\text { pengayaan }\end{array}$ \\
\hline & & peduli lingkungan & tidak mencabut tanaman dan & menunjukkan upaya \\
\hline
\end{tabular}




\begin{tabular}{|c|c|c|c|c|}
\hline \multirow{2}{*}{$\begin{array}{c}\text { Standar } \\
\text { Kompeten-si }\end{array}$} & \multirow{2}{*}{$\begin{array}{c}\text { Kompetensi } \\
\text { Dasar }\end{array}$} & \multirow{2}{*}{ Nilai } & \multicolumn{2}{|c|}{ Indikator Berdasarkan Jenjang Kelas } \\
\hline & & & $1-3$ & $4-6$ \\
\hline & & & $\begin{array}{l}\text { memetik bunga di halaman } \\
\text { sekolah }\end{array}$ & $\begin{array}{l}\text { turut serta dalam } \\
\text { merawat tanaman di } \\
\text { lingkungan sekolah } \\
\text { seperti menyiram dan } \\
\text { menyiangi tanaman }\end{array}$ \\
\hline & & & $\begin{array}{l}\text { menunjukkan upaya turut serta } \\
\text { dalam merawat tanaman di } \\
\text { pekarangan kelas seperti } \\
\text { menyiram tanaman pada pot }\end{array}$ & $\begin{array}{l}\text { mengemukakan } \\
\text { pendapat/ saran untuk } \\
\text { memelihara tanaman } \\
\text { dan lingkungan } \\
\text { sekolah. }\end{array}$ \\
\hline \multirow{5}{*}{$\begin{array}{l}\text { mengenal } \\
\text { berbagai } \\
\text { sifat benda } \\
\text { dan } \\
\text { kegunaannya } \\
\text { melalui } \\
\text { pengamatan } \\
\text { perubahan } \\
\text { bentuk benda }\end{array}$} & $\begin{array}{l}\text { mengidentifikasi } \\
\text { benda yang ada di } \\
\text { lingkungan sekitar } \\
\text { berdasarkan cirinya } \\
\text { melalui pengamatan }\end{array}$ & $\begin{array}{l}\text { menghargai } \\
\text { prestasi }\end{array}$ & $\begin{array}{l}\text { berusaha mendapatkan nilai } \\
\text { yanag sempurna dari tugas yang } \\
\text { diberikan. }\end{array}$ & $\begin{array}{l}\text { memberikan } \\
\text { penghargaan kepada } \\
\text { teman yang berprestasi }\end{array}$ \\
\hline & & jujur & $\begin{array}{l}\text { mengungkapkan secara ciri-ciri } \\
\text { benda yang dapat diamati di } \\
\text { lingkungan sekitar }\end{array}$ & $\begin{array}{l}\text { melaporkan secara } \\
\text { jujur hasil pengamatan } \\
\text { mengenai benda di } \\
\text { sekitarnya }\end{array}$ \\
\hline & & $\begin{array}{l}\text { bersahabat/ } \\
\text { komunikatif }\end{array}$ & $\begin{array}{l}\text { mengungkapkan secara jelas } \\
\text { benda-benda yang dapat } \\
\text { diamati di lingkungan sekitar }\end{array}$ & $\begin{array}{l}\text { turut dalam diskusi } \\
\text { kelas }\end{array}$ \\
\hline & & peduli sosial & $\begin{array}{l}\text { mendengar dan menyimak } \\
\text { penjelasan guru dan teman } \\
\text { sekelas }\end{array}$ & $\begin{array}{l}\text { menjawab pertanyaan } \\
\text { teman sekelas }\end{array}$ \\
\hline & & senang membaca & $\begin{array}{l}\text { menceritakan hal yang telah } \\
\text { difahami dalam } \\
\text { membaca. }\end{array}$ & $\begin{array}{l}\text { membicarakan is } \\
\text { buku/tulisan yang } \\
\text { dibacanya di kelas }\end{array}$ \\
\hline
\end{tabular}

Indikator keberhasilan pengintegrasian pendidikan karakter pada mata pelajaran IPA di Madrasah Ibtidaiyah merujuk pada tujuan pembelajaran IPA di Madrasah Ibtidaiyah yang telah dicantumkan dalam kurikulum tingkat satuan pendidikan, yaitu:

1) Memperoleh keyakinan terhadap kebesaran Tuhan YME berdasarkan keberadaan, keindahan, dan keteraturan-Nya

2) Mengembangkan pengetahuan dan pemahaman konsep IPA yang bermanfaat dan dapat diterapkan dalam kehidupan sehari-hari

3) Mengembangkan rasa ingin tahu, sikap positif dan kesadaran tentang adanya hubungan yang saling mempengaruhi antara IPA, lingkungan, teknologi dan masyarakat

4) Mengembangkan keterampilan proses untuk menyelidiki alam sekitar, memecahkan masalah dan membuat keputusan

5) Meningkatkan kesadaran untuk berperan serta dalam memelihara, menjaga dan melestarikan lingkungan alam

6) Meningkatkan kesadaran untuk menghargai alam dan segala keteraturannya sebagai salah satu ciptaan Tuhan 
7) Memperoleh bekal pengetahuan, konsep, dan keterampilan IPA sebagai dasar untuk melanjutkan pendidikan ke SMP/MTs, (BSNP, 2006).

\section{SIMPULAN}

Pendidikan karakter religius dalam IPA bukan merupakan mata pelajaran yang berdiri sendiri atau merupakan nilai yang diajarkan, tetapi lebih kepada upaya penanaman nilai-nilai yang dilakukan secara terintegrasi dalam mata pelajaran IPA. Aspek yang harus diperhatikan dalam menanamkan karakter religius dalam IPA adalah mengaitkan nilai-nilai tersebut secara eksplisit dalam perencanaan pembelajaraan, pelaksanaan pembelajaran dan penilaian pembelajaran yang disesuaikan dengan karakteristik mata pelajaran IPA. pengintegrasian karakter religius pada mata pelajaran IPA disesuaikan dengan hakikat IPA yang menekankan pada aspek IPA sebagai produk, IPA sebagai proses dan IPA sebagai sikap. Nilai-nilai yang dapat ditanamkan melalui proses pembiasaan pada mata pelajaran IPA di Madrasah Ibtidaiyah tidak hanya sebatas nilai religius dalam arti sempit tetapi juga nilai-nilai religius dalam arti luas seperti, jujur, toleransi, disiplin, kerja keras, kreatif, mandiri, demokratis, rasa ingin tahu, semangat kebangsaan, cinta tanah air, menghargai prestasi, bersahabat/komunikatif, cinta damai, gemar membaca, peduli lingkungan, peduli sosial, dan tanggung jawab. Hal ini sejalan dengan aspek sikap ilmiah dalam IPA yang dapat dikembangkan pada siswa Madrasah Ibtidaiyah, yaitu: (1) sikap ingin tahu, (2) sikap ingin mendapatkan sesuatu yang baru, (3) sikap kerja sama, (4) sikap tidak putus asa, (5) sikap tidak berprasangka, (6) sikap mawas diri, (7) sikap bertanggung jawab, (8) sikap berpikir bebas, dan (9) sikap kedisiplinan diri.

\section{DAFTAR PUSTAKA}

Abruscato, J. 1982. Teaching Children Science. New Jersey: Prentice Hall, Inc.

BSNP. 2006. Panduan Penyusunan Kurikulum Tingkat Satuan Pendidikan Jenjang Pendidikan Dasar. Jakarta.

Carin, A.A. 1997. Teaching Science Thought Discovery. 8th Edition. New Jersey: Prentice Hall, Inc.

Firman, H., dan Ari Widodo. 2007. Buku Panduan Pendidik Ilmu Pengetabuan Alam Madrasah ibtidaiyah. Jakarta: Pusat Perbukuan Depdiknas.

Harlen, W. 1992. The Teaching Science: Studies in Primary Education. London: David Fulton Publishers.

Instruksi Presiden Nomor 1 tahun 2010 tentang Percepatan Pelaksanaan Prioritas Pembangunan Tahun 2010.

Iskandar, S.M. 1996. Pendidikan Ilmu Pengetahuan Alam. Jakarta: Depdikbud Dirjen Dikti.

Kemendiknas. 2010. Pedoman Sekolab: Pengembangan Pendidikan Budaya dan Karakter Bangsa. Jakarta: Kementerian Pendidikan Nasional Badan penelitian dan Pengembangan Pusat Kurikulum. 
Liem, T.L. 2007. Asyiknya Meneliti IPA (Invitation to Science Inquiry). Bandung: Pudak Scientific.

Megawangi, Ratna. 2009. Pendidikan Karakter Solusi yang Tepat untuk Membangun Bangsa. Jakarta: Indonesia Heritage Foundation.

Munir, Abdullah. 2010. Pendidikan Karakter: Membangun Karakter Anak Sejak dari Rumah. Yogyakarta: Pedagogia.

Muslich, Masnur. 2011. Pendidikan Karakter Menjawab Tantangan Krisi Multidimensional. Jakarta: Bumi Aksara.

Nugraha, A. 2008. Pengembangan Pembelajaran IP A pada Anak Usia Dini. Bandung: JILSI Foundation.

Poedjiadi, A.1987. Sejarah dan Filsafat IPA. Bandung: Fakultas Pascasarjana IKIP Bandung.

Pusat Kurikulum. 2007. Naskah Akademik Kajian Kebijakan Kurikulum Mata Pelajaran IPA. Jakarta: Pusat Kurikulum Badan Penelitian dan Pengembangan Departemen Pendidikan Nasional.

Sudrajat, Akhmad. 2010. Tentang Pendidikan Karakter. [On Line]. Tersedia di: http://akhmadsudrajat.wordpress.com. [06 Desember 2011].

Sund, R.B. and Trowbridge, L.W. 1973. Teaching Science by Inquiryin the Secondary School. Columbus: Charles E. Merill Publishing Company, A Bell \& Howell Company.

Sutrisno, L. Hery, K., dan Kartono. 2007. Bahan Ajar Cetak: Pengembangan Pembelajaran IPA SD. Jakarta: Direktorat Jenderal Pendidikan Tinggi Departemen Pendidikan Nasional.

Undang-undang No. 20 Tahun 2003 tentang Sistem Pendidikan Nasional. 